\title{
PKM GEMAR MAKAN IKAN UNTUK KECERDASAN ANAK SEKOLAH DI SDN 82/IV SEJINJANG KOTA JAMBI
}

\author{
Dini Junita ${ }^{1}$, Dini Wulan Dari ${ }^{2)}$ \\ ${ }^{1}$ Program Studi Ilmu Gizi, STIKes Baiturrahim Jambi (penulis 1) \\ ${ }^{2}$ Program Studi Ilmu Gizi, STIKes Baiturrahim Jambi (penulis 2) \\ email: dinijunita.dj.dj@gmail.com
}

\begin{abstract}
Health efforts for children can be done through improving nutrition, especially in elementary school age. Good nutrition will produce quality human resources. One of the important nutrients for growth and development of school children is a protein derived from fish. This service activity applies leaflets and modules in conveying the message of the importance of fish consumption, involving the role of class teachers in transforming the benefits of fish consumption to students on an ongoing basis, exploring the factors that influence children in consuming fish. So that it is expected to increase the knowledge of the target and know the factors that influence the target in consuming fish. The results of this activity concluded that there was an increase in the knowledge of the target group about the importance of fish consumption, but it could not be ascertained the application in daily practice. So it needs to be monitored in its implementation. Knowledge and motivation are not the main factors children want to consume fish, the availability of food made from fish in the home and processing that can increase children's interest in fish consumption is the main factor that needs attention.
\end{abstract}

Keywords: fish-consumption; intelligence-nutrition; school-age.

\begin{abstract}
ABSTRAK
Upaya kesehatan pada anak dapat dilakukan melalui perbaikan gizi terutama di usia sekolah dasar. Gizi yang baik akan menghasilkan SDM yang berkualitas. Salah satu zat gizi penting bagi tumbuh kembang anak sekolah adalah protein yang berasal dari ikan. Kegiatan pengabdian ini menerapkan leaflet dan modul dalam menyampaikan pesan pentingnya konsumsi ikan, melibatkan peran guru kelas dalam mentransformasikan manfaat konsumsi ikan kepada siswa/i secara berkesinambungan, menggali faktor-faktor yang mempengaruhi anak dalam konsumsi ikan. Sehingga diharapkan dapat meningkatkan pengetahuan sasaran dan diketahui faktor yang mempengaruhi sasaran dalam mengkonsumsi ikan. Hasil kegiatan ini menyimpulkan bahwa terjadi peningkatan pengetahuan kelompok sasaran tentang pentingnya konsumsi ikan, tetapi belum dapat dipastikan penerapan dalam praktik sehari-hari. Sehingga perlu dilakukan pemantauan dalam implementasinya. Pengetahuan dan motivasi bukanlah faktor utama anak mau konsumsi ikan, ketersediaan pangan berbahan ikan di rumah dan pengolahan yang dapat meningkatkan minat anak untuk konsumsi ikan merupakan faktor utama yang perlu diperhatikan.
\end{abstract}

Kata kunci : anak sekolah; gizi kecerdasan; konsumsi ikan.

\section{PENDAHULUAN}

Anak-anak merupakan cikal bakal generasi penerus bangsa. Pembentukan kualitas anak sejak masa sekolah akan mempengaruhi kualitas akan menentukan Sumber Daya Manusia (SDM) saat mereka mencapai usia produktif. Anak usia sekolah adalah golongan yang memerlukan perhatian dalam konsumsi makanan dan zat gizi. Tumbuh dan berkembangnya anak usia 
sekolah yang optimal tergantung pemberian nutrisi dengan kualitas dan kuantitas yang baik serta benar (Restuastuti, 2012).

Upaya kesehatan pada anak dapat dilakukan melalui perbaikan gizi terutama di usia sekolah dasar yaitu usia 7-12 tahun. Gizi yang baik akan menghasilkan SDM yang berkualitas, yaitu sehat, cerdas, dan memiliki fisik yang tanggung serta produktif. Jadi, perbaikan gizi anak sekolah dasar khususnya merupakan langkah strategis karena dampaknya secara langsung berkaitan dengan pencapaian SDM yang berkualitas (Depkes RI, 2005).

Salah satu faktor yang mempengaruhi status gizi anak adalah kebiasaan makan. Anak cenderung memilih makanan yang disukai dan menyisihkan yang tidak disukai, misalnya jenis sayuran dan ikan. Salah satu zat gizi penting bagi tumbuh kembang anak sekolah adalah protein. Ikan sebagai sumber protein merupakan bahan pangan yang murah, bernilai gizi tinggi dengan kualitas protein yang mudah dicerna serta dapat diolah dengan berbagai macam olahan. Protein ikan menyediakan lebih kurang 2/3 dari kebutuhan protein hewani yang diperlukan oleh manusia dan kandungan protein ikan relatif besar yaitu antara $15-25 \%$ per 100 gram daging ikan.

Disamping menyediakan protein hewani yang relatif tinggi, ikan juga mengandung lemak (minyak ikan) antara $0,2-24 \%$ terutama asam lemak esensial termasuk omega-3 (yang masuk dalam kelompok omega-3 adalah asam linolenat, Eicosa Pentaenoic Acid (EPA), dan Docosa Heksaenoic Acid (DHA). Ketiganya ini disebut asam lemak esensial karena sangat penting termasuk dalam meningkatkan kecerdasan, sehingga mempengaruhi prestasi anak di sekolah (Riyandini et al. 2014).

Rasa dan aroma ikan yang amis menjadi alasan anak tidak memilih ikan sebagai sumber protein hewani. Hal ini diperburuk oleh kondisi ekonomi masyarakat yang rata-rata menengah ke bawah juga menjadi salah satu faktor rendahnya konsumsi ikan siswa Sekolah Dasar, padahal ketersediaan ikan di lingkungan sekitar cukup. Selain itu, faktor pengetahuan juga mempengaruhi keinginan untuk mengkonsumsi ikan (Putri et al. 2015). Menurut Khomsan (2010) jika kita menghendaki agar masyarakat gemar makan ikan, maka diperlukan peningkatan pengetahuan, sehingga mereka mengetahui manfaat positif mengkonsumsi ikan bagi kesehatan.

Kegiatan ini akan memberikan pendidikan gizi berupa penyuluhan di sekolah karena lingkungan sekolah sangat efektif dan mudah dijangkau. Mitra yang dipilih dalam kegiatan pengabdian masyarakat adalah Sekolah Dasar (SD) Sejinjang Kota Jambi. SDN 82/IV Sejinjang merupakan salah satu SD Negeri yang berada di wilayah Kota Jambi. Secara geografis lingkungan SDN 82/IV Sejinjang merupakan dataran rendah dan rawa yang memiliki potensi cukup baik sebagai penghasil ikan. Masyarakat biasanya memperoleh ikan dengan cara memancing di rawa ataupun membeli di pasar tradisional dan pasar musiman. Ketersediaan ikan membuat jenis pangan hewani ini menjadi pilihan utama bagi masyarakat dalam memenuhi kebutuhan protein anak. Hal ini tentu akan berdampak baik jika diiringi dengan stimulasi ke anak untuk mau mengkonsumsi ikan. Oleh karena itu, tim pengabdian masyarakat tertarik untuk melakukan kegiatan pengabdian kepada masyarakat agar menjadi stimulus dan memunculkan motivasi anak untuk gemar mengkonsumsi ikan dengan judul "Gemar Makan Ikan untuk Kecerdasan Anak Sekolah di SDN 82/IV Sejinjang Kota Jambi”

\section{TARGET DAN LUARAN}

Kegiatan pengabdian ini memiliki target yaitu: 
1. Kehadiran siswa/i kelas IV dan V SDN 82/IV Sejinjang Kota Jambi total 60 orang.

2. Sasaran memiliki pengetahuan baik tentang pentingnya konsumsi ikan pada anak sekolah. Indikator pengetahuan baik yaitu $\geq 80 \%$ sasaran dapat menjawab dengan benar pertanyaan pada lembar post-test.

3. Diketahuinya factor yang mempengaruhi sasaran dalam mengkonsumsi ikan.

Adapun luaran dari kegiatan pengabdian selain artikel ilmiah yaitu:

1. Media leaflet dan poster gemar makan ikan pada anak sekolah

2. Peningkatan pengetahuan tentang baiknya makan ikan pada anak sekolah

3. Rekomendasi dalam upaya meningkatkan konsumsi ikan pada anak

\section{METODE PELAKSANAAN}

Kegiatan ini telah dilaksanakan pada bulan Maret s/d Mei 2018 di SDN 82/IV Sijenjang, Kota Jambi. yaitu:

Tujuan dari kegiatan pengabdian ini

1) Menciptakan leaflet dan modul yang efektif dalam menyampaikan pesan pentingnya konsumsi ikan

2) Guru kelas dapat mentransformasikan manfaat konsumsi ikan kepada siswa/i secara berkesinambungan

3) Diketahuinya factor-faktor yang mempengaruhi anak dalam konsumsi ikan

Sasaran dalam kegiatan ini adalah siswa/siswi kelas IV dan V SDN 82/IV Sijenjang, Kota Jambi. Pemilihan sasaran dengan kisaran usia 10 - 11 tahun dengan alasan lebih komunikatif dan dianggap mampu memahami informasi yang diberikan sehingga dapat memberikan feedback yang ingin diketahui. Total sasaran adalah 60 orang siswa/siswi dan 6 orang guru kelas IV dan V. Adapun kontribusi sasaran dalam pengabdian masyarakat ini adalah:
1) Menjadi peserta kegiatan pengabdian

2) Siswa siswi mengikuti pre dan post test

3) Guru menjadi fasilitator bagi siswa/siswi lainnya dalam meningkatkan pengetahuan tentang manfaat konsumsi ikan

\section{Pelaksanaan Kegiatan}

Tahapan pelaksanaan kegiatan pengabdian kepada masyarakat ini adalah sebagai berikut:

\section{Kegiatan Awal}

a) Menyusun proposal kegiatan pengabdian kepada masyarakat.

b) Mendesain poster dan leaflet gemar makan ikan pada anak sekolah.

c) Menyiapkan materi presentasi manfaat konsumsi ikan pada anak sekolah untuk disampaikan kepada sasaran

d) Menyiapkan lembar pre-test dan post test tentang pengetahuan terkait konsumsi ikan pada anak sekolah.

e) Menyiapkan materi grup diskusi bersama guru mengenai kegiatan dan sasaran kegiatan

\section{Pelaksanaan Kegiatan}

a) Perkenalan antara tim pengabdian kepada masyarakat dengan sasaran

b) Melakukan grup diskusi bersama guru mengenai kegiatan dan sasaran kegiatan

c) Penjelasan kegiatan yang akan dilakukan dalam melibatkan sasaran

d) Memberikan lembar pre-test

e) Melaksanakan penyampaian pesan manfaat konsumsi ikan pada anak sekolah melalui media poster dan leafleat.

f) Memberikan stimulasi dan motivasi pada anak untuk mau konsumsi ikan

g) Memberikan lembar post-test

h) Penutupan

\section{Monitoring dan Evaluasi}

Monitoring dan evaluasi (Monev) dilakukan dengan teknik wawancara dan observasi langsung kepada sasaran. 
Cakupan Monev dalam kegiatan ini meliputi empat aspsek, yaitu sebagai berikut:

\section{1) Monev Perencanaan}

Pada aspek ini tim akan mengevaluasi kondisi mitra, tujuan program, permasalahan dan pemacahan masalah mitra, isi materi dan praktik kegiatan, media/ alat yang digunakan, sasaran dalam kegiatan pengabdian, waktu pelaksanaan evaluasi (berapa lama, dan kapan evaluasi dilaksanakan), sarana dan prasaran, dan dana yang digunakan.

\section{2) Monev Pelaksanaan Kegiatan}

Indikator keberhasilan pada aspek ini adalah:

a. Sebanyak 90-100\% sasaran menghadiri setiap pertemuan pada kegiatan pengabdian.

b. Kemampuan tim dalam menyampaikan materi dan praktik kepada sasaran.

c. Refleksi dan umpan balik dari peserta kegiatan.

d. Perilaku gemar makan ikan dapat dilaksanakan oleh sasaran.

\section{HASIL DAN PEMBAHASAN}

1. Gambaran Umum Lokasi Pengabdian SD Negeri SDN 82/IV Sijenjang Kota Jambi memiliki Jumlah siswa/siswi di SD sebanyak 160 orang. SDN 82/IV Sijenjang merupakan dataran rendah dan rawa yang memiliki potensi cukup baik sebagai penghasil ikan. Masyarakat biasanya memperoleh ikan dengan cara memancing di rawa ataupun membeli di pasar tradisional dan pasar musiman. Ketersediaan ikan membuat jenis pangan hewani ini menjadi pilihan utama bagi masyarakat dalam memenuhi kebutuhan protein anak. Hal ini tentu akan berdampak baik jika diiringi dengan stimulasi ke anak untuk mau mengkonsumsi ikan.
Sasaran dalam kegiatan ini adalah seluruh siswa/siswi kelas IV danV di SDN 82/IV Kota Jambi. Pada pelaksanaannya semua siswa/i menghadiri kegiatan sampai selesai sehingga capaian sasaran dalam kegiatan ini $100 \%$. Kegiatan ini didampingi oleh guru wali kelas IV dan $\mathrm{V}$ sehingga diharapkan guru tersebut dapat mentransformasikan ilmu yang disampaikan serta memotivasi siswa/I untuk makan ikan secara berkesinambungan.

Sebelum diedukasi mengenai materi pentingnya konsumsi ikan, siswa/siswi diberikan soal pre-test untuk mengukur pengetahuan awal sebelum diberikan penyuluhan. Pemberian materi disampaikan oleh 1 orang dosen yang ahli dibidang gizi yaitu ketua pengabdian serta dibantu oleh 3 orang mahasiswa dalam pelaksanaan teknik pengabdian. Setelah dilakukan penyuluhan, sasaran diberikan soal post-test untuk mengukur pengetahuan sasaran setelah diberikan penyuluhan.

Selain itu, pada pelaksanaan tim pengabdian juga mempraktikkan cara memilih jajanan yang sehat, konsumsi sayur dan buah sehingga diharapkan meningkatkan pengetahuan siswa/i lebih baik.

3. Hasil Kegiatan

Berdasarkan hasil focus grup diskusi para guru memahami pentingnya makan ikan dan mau ikut memberikan pendampingan kepada siswa-siswi di sekolah dalam memilih jajanan yang sehat dan bergizi. Guru memahami isi poster dan dapat menyampaikan informasi sesuai harapan.

Kegiatan pengabdian diikuti oleh 57 peserta, gabungan kelas IV dan V. Selanjutnya saat pelaksanaan pemberian edukasi, siswa siswi yang menjadi target sasaran kegiatan ini merespon dengan baik terlihat dari adanya interaksi siswa/siswi ketika diberikan pertanyaan-pertanyaan langsung, berkomentar tentang gambar

2. Pelaksanaan Kegiatan 
dalam poster ataupun informasi yang diberikan.

Berdasarkan hasil pre-test diketahui bahwa sebanyak 12 siswa/i (30\%) menjawab salah pertanyaan mengenai manfaat mengkonsumsi ikan. dan sebanyak 34 siswa/i $(60,7 \%)$ menjawab makan ikan dapat menyebabkan cacingan. Namun, setelah diberikan penyuluhan $80 \%$ sasaran dapat menjawab pertanyaan post-test dengan benar.

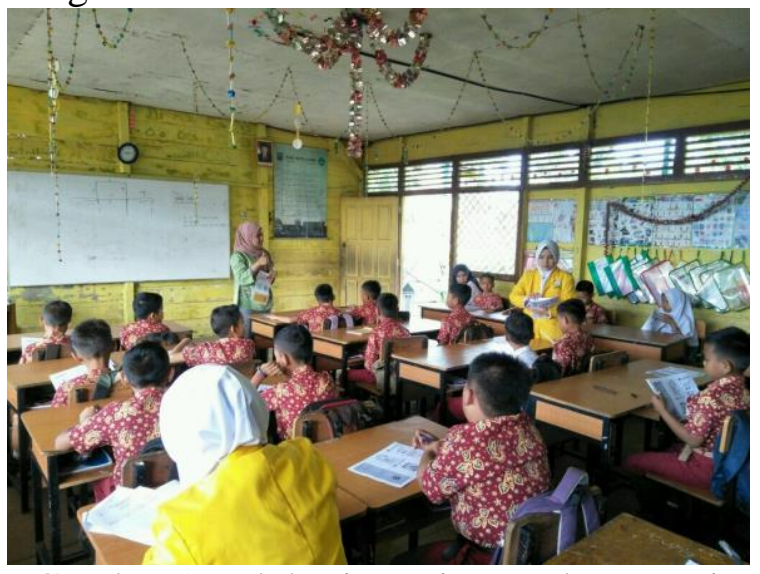

Gambar 1. Edukasi Pentingnya konsumsi ikan

Di akhir kegiatan masih terdapat beberapa siswa/siswi yang menyampaikan tetap tidak menyukai ikan dan tidak mau mengkonsumsi ikan. Beberapa alasan yang dikemukakan oleh sasaran terkait rendahnya minat untuk mengkonsumsi ikan yaitu aroma amis yang kuat pada ikan, duri yang banyak sehingga sulit ketika makan, rasa yang kurang enak terutama pada jenis ikan air tawar.

Saat proses edukasi pemateri memberikan alternative solusi dalam mengatasi alasan-alasan yang dikemukakan anak dalam penyebab kurangnya minat konsumsi ikan. Beberapa solusi yang diberikan adalah konsumsi produk olahan berbahan dasar ikan seperti bakso ikan, tekwan, pempek, otak-otak, nugget ikan. Sehingga sasaran dapat mengerti mereka dapat mengkonsumsi ikan dengan rasa, aroma serta cara yang lebih enak dan tidak ada alasan untuk tidak mau konsumsi ikan.

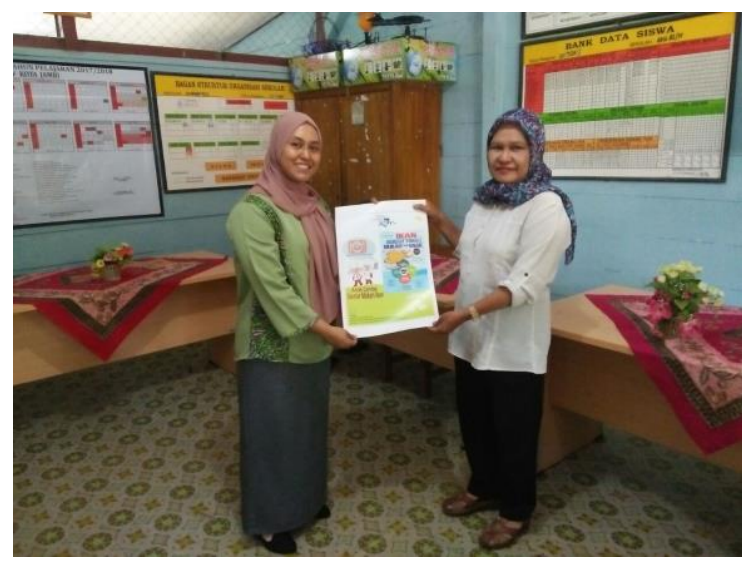

Gambar 2 Simbolisasi Penyerahan Media Poster

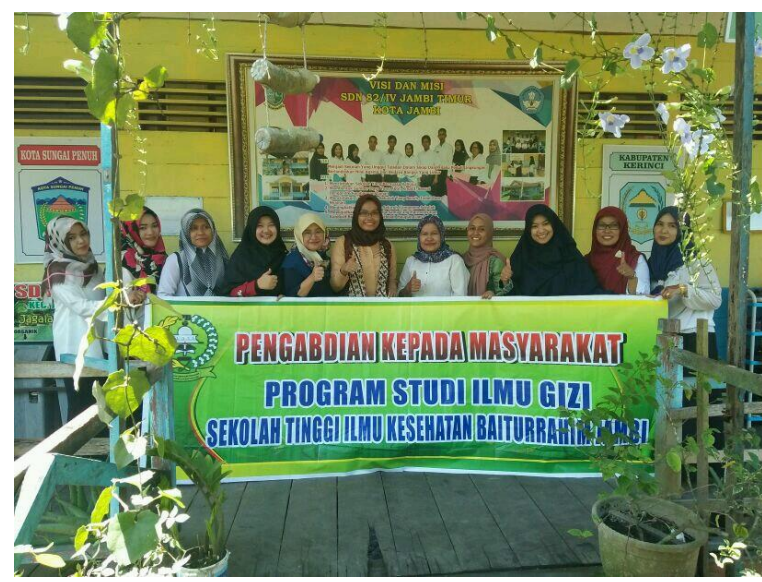

Gambar 3. Tim Pengabdian bersama guru

\section{KESIMPULAN DAN SARAN}

\section{Kesimpulan}

Meskipun menunjukkan peningkatan pengetahuan kelompok sasaran tentang pentingnya konsumsi ikan, tetapi belum dapat dipastikan dalam praktik sehari-hari. Sehingga perlu dilakukan pemantauan dalam impelemtasinya. Pengetahuan dan motivasi bukanlah factor utama anak mau konsumsi ikan, ketersediaan pangan berbahan ikan di rumah dan pengolahan yang dapat meningkatkan minat anak untuk konsumsi ikan merupakan factor utama yang perlu diperhatikan. Terkait hal tersebut perlu peran dan dukungan keluarga dalam mewujudkannya. 


\section{Saran}

Perlu dilakukan pemantauan dalam implementasi konsumsi ikan pada anak sekolah melalui penelitian kualitas konsumsi individu. Selain itu perlu dikasji peran dan dukungan keluarga dalam mewujudkan kualitas konsumsi ikan pada anak.

\section{UCAPAN TERIMAKASIH}

Pengabdi mengucapkan terimakasih kepada STIKes Baiturrahim Jambi atas dukungan moril serta materi yang bersumber dari dana pengabdian internal STIKBA sehingga kegiatan ini dapat terlaksana dengan baik.

\section{DAFTAR PUSTAKA}

Depkes RI. 2005. Pedoman Perbaikan Gizi Anak Sekolah Dasar dan Madrasah Ibtidaiyah.Direktorat Jendral Bina Kesehatan Masyarakat, Jakarta.

Khomsan A. 2010. Pangan dan Gizi Untuk Kesehatan. PT Rajagrafindo Persada. Jakarta.

Putri AM, Jumirah, Siagian A. 2015. Faktor-Faktor Yang Berhubungan Dengan Pola Konsumsi Ikan Siswa Sekolah Dasar Negeri 060919 Di Kecamatan Medan Sunggal.Skripsi. Medan:Univ. Sumatera Utara.

Restuastuti T, Handayani, Ernalia Y. 2012. Penilaian Status Gizi Anak usia Sekolah Dasar dan Pelatihan Pangan Jajanan Sehat Anak Sekolah Dasar di Pekanbaru. [Laporan Pengabdian Masyarakat]. Pekanbaru: Universitas Riau.

Riyandini MC, Sudaryati E, Siagian A. 2014. Hubungan Konsumsi Ikan Dengan Prestasi Belajar Anak Di Sekolah Dasar Swasta Brigjend
Katamso II Kecamatan Medan Marelan Kota Medan. Skripsi. Medan:Univ. Sumatera Utara. 